\title{
Association of Temporomandibular Dysfunction and Stress in University Students
}

\author{
Asociación de Disfunción Temporomandibular y Estrés en Estudiantes Universitarios
}

\author{
Caroline D.T. Riffel"; Mateus E. Flores* ${ }^{* *}$ Jamile T. Scorsatto $^{* * *}$; \\ Liliane V. Ceccon ${ }^{* * *}$; Ferdinando De Conto ${ }^{* * * *} \&$ Gisele Rovani ${ }^{* * * *}$
}

RIFFEL, C. D. T.; FLORES, M. E.; SCORSATTO, J. T.; CECCON, L. V.; DE CONTO, F. \& ROVANI, G. Association of temporomandibular dysfunction and stress in university students. Int. J. Odontostomat., 9(2):191-197, 2015.

ABSTRACT: The aim of this study was to evaluate the influence of emotional factors in temporomandibular disorders (TMD) in university students. The universe of this study consisted of 696 students of both sexes, from the University of Passo Fundo (UPF) - RS, who signed the free and informed consent term and received the Fonseca's Questionnaire, in order to verify the level of TMD and the Social Readjustment Rating Scale (SRRS), to evaluate the degree of stress level, at the beginning and end of the semester, beginners and graduating students. Data were tabulated and statistically analyzed using the Chi-Square test, with the significance level of $5 \%$. From the total, 489 (70.25\%) subjects had some degree of TMD, being the light TMD the most prevalent (309) in all areas of knowledge, with no statistical difference between the studied areas $(p=0.004)$. There was correlation between TMD and stress-SRRS ( $r=0.217)$. There is a low percentage of individuals who are free from TMD. The correlation between TMD and stress was weak in all studied groups, regardless the area of knowledge, academic period and school grade. syndrome.

KEY WORDS: temporomandibular joint, facial pain, psychological stress, temporomandibular joint dysfunction

\section{INTRODUCTION}

Pain is defined as an unpleasant sensorial and emotional experience that is associated with real or potential tissue damage, or described in terms. Not only the physical and chemical components involved in pain are considered, but also the psychological and subjective aspects, crucial in the understanding the complaint (Ferreira et al., 2009). Chronic pain is one of the major causes of physical and psychosocial suffering, as well of faults and absences from work because of deficiency (Sessle, 2000; Carlsson et al., 2006).

The TMD is defined as a collection of functional and pathological conditions that affect the temporomandibular joint (TMJ), the masticatory muscles and the tissue components as a whole directly affect the entire individual's stomatognathic system (Fonseca et al., 1994). It is one of the most common diagnoses of orofacial chronic pain, associated to emotional and psychological, behavioral and cognitive factors (Nóbrega et al., 2007) affecting both, adults and children, ranging from $31 \%$ to $60 \%$ of the population, being present at some degree and time, as evidenced by signs or symptoms, also that there are more people completely free of TMD (Okeson, 2000; Nekora-Azak et al., 2006; Martins et al., 2007, 2010; Nomura et al., 2007). It is a pathology ranging from symptoms of pain and joint noise, crepitation, restriction of mandibular movements, especially of the mouth opening (Dworkin et al., 1990), shifts lightest to severe and disabling, which prevent the individual from exercising their physiological functions, normal for speech and feeding, for example, until their daily activities, such as work, leisure and rest. Also headaches, nape, neck, ears and face (Fonseca et al.). Thailander et al. (2002) devoted careful study on the multifactorial etiology.

MSc., University of Passo Fundo, Passo Fundo, Brazil.

* Department of Radiology, University of Passo Fundo, Passo Fundo, Brazil.

*** Academic dentistry, Faculty of Dentistry, University of Passo Fundo, Passo Fundo, Brazil.

*.** Department of Surgery, University of Passo Fundo, Passo Fundo, Brazil.

${ }^{* * *+*}$ Department of Oral Pathology, University of Passo Fundo, Passo Fundo, Brazil. 
The Fonseca's Questionnaire (Fonseca et al.) is a simplified anamnestic index that detects signs/ symptoms and the severity of TMD, and, the degree of dysfunction. Consists of a specific clinical record with ten questions, which includes anamnesis and physical examination. For each question are possible the answers "yes", "no" and "sometimes". The answers have the following valuations: yes $=10$, sometimes $=5$, no $=0$. The individual is classified according to the values found: $0-15$ (no TMD), 20-40 (mild TMD), 4565 (moderate TMD) and 70-100 (severe TMD).

The Social Readjustment Rating Scale developed by Holmes \& Rahe (1967) is based on the premise that good and bad moments of individuals' life can increase his stress level. Consists of a series of 43 life events, including positive events, negative, frequent and rare that occurred in the last 12 months. Predetermined and varied valuations are attributed for each question/event signaled (for example, since 11, for minor violations of the law, up to 100 , for the death of a spouse), which sum makes up the total score. The obtained score will determine the chance of the individual to present the problem in the following two years, depending on the range in which the individual fit into (30\% - less than or equal to 150 points, $50 \%$ - between $150-300$ points, $80 \%$ - above 300 points). According to Holmes \& Rahe, regardless of the nature or category of each one of the events, there is a common denominator to all of them - their occurrence causes an adaptive behavior on the part of those who live them. This finding is the operationalized idea of life event.

\section{MATERIAL AND METHOD}

After the research, the project was approved by the Research Ethics Committee on April 3rd of 2012, having protocol number 062/2012, the implementation was initiated with the application of two validated questionnaires.

The sample of this research consisted of 696 students of both sexes, of the University of Passo Fundo (UPF), in Passo Fundo, estate of RS, Brazil. These students were divided into groups according to the following areas of knowledge: Engineering, Linguistics, Letters and Arts, Health and Applied Social.

Each knowledge area consisted of two subgroups: beginners (students of the first year) and senior students (from the last year). Each group had a minimum of forty surveyed subjects. The tests were applied in two stages: at the beginning and end of the term of the year 2012 .

The first in order to identify symptoms of TMD, elaborated by Fonseca et al., and the second, the Social Readjustment Rating Scale (SRRS), elaborated by Holmes \& Rahe, to evaluate the degree of stress. The Term of Free and Informed Consent (TFIC) was present in all questionnaires. There wasn't a time limit for conclusion of the questionnaires, so there wasn't reason for respondents to give induced responses. Participants were informed about the objectives of the study and about how to participate, and those who agreed signed a consent form, which was attached to the questionnaires. To each participant student was given a code number in order to safeguard his/her identity.

On the header of the questionnaire used by the authors, there were some requirements to be fulfilled by the respondent, such as sex, age, the faculty that the student was attending, as well as the semester.

Interviews were conducted by the researchers on university students who were regularly attending undergraduate courses of the four areas of knowledge (Engineering, Linguistics, Letters and Arts, Health and Applied Social). The application was done in classrooms, in common areas of the faculties (corridors, cafeterias) and in a social center of the UPF. The period of implementation of the first phase lasted three weeks and was completed by the end of June, before the end of the semester. The second stage of the questionnaires took place in early August 2012 and was completed at the end of this same month.

The results obtained with the questionnaire application were tabulated on Excel spreadsheets and analyzed statistically and descriptively, and, through the Chi-Square Test $\left(X^{2}\right)$, at significance level of $5 \%$ and Spearman correlation, since the data obtained are qualitative, except ages (quantitative).

\section{RESULTS}

Of the 718 respondents, 22 were excluded due to the fact that they did not sign the consent form and that they weren't enrolled in the semesters that were specified in the survey methodology. The sample was comprised of 696 participants, $149(21.4 \%)$ of Engineering, $156(22.4 \%)$ of Letters, Arts and 


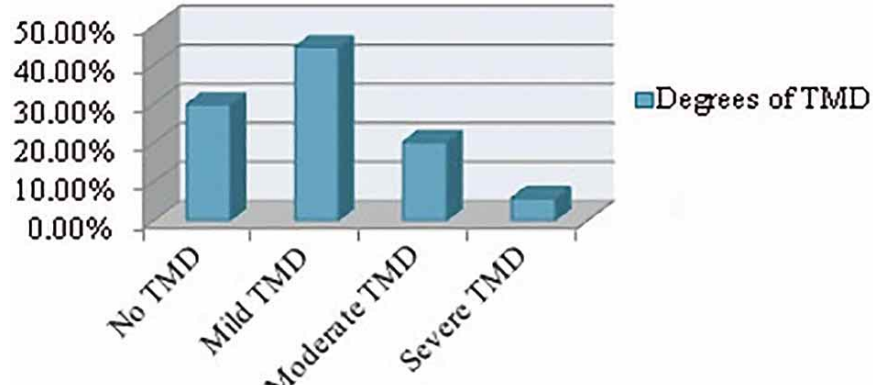

Fig. 1 Results of Fonseca's Questionnaire applied to students of both sexes, of the University of Passo Fundo (UPF), in Passo Fundo, estate of RS, Brazil. TMD (Temporomandibular disorders)

Linguistics, $171(24.6 \%)$ of Health, 220 (31.6\%) of Applied Social area. We interviewed 350 beginner students (students of the first year) and 346 senior students (from the lastyear). The age of participants varied from 17 to 54 years, being the average age 21.7 years +-4.57 years and the median of 21 years. Regarding sex, 257 (36.9\%) were male and 439 (63.1\%) female.

Of the results of Fonseca's Questionnaire, 207 interviewed (29.7\%) did not have any degree of TMD, 309
(44.4\%) had mild TMD, $140(20.1 \%)$ moderate TMD and $40(5.7 \%)$ severe TMD (Fig. 1).

The results of the questionnaires about stress (Fig. 2) showed that stress 221 (31.8\%) presented low stress, 78 (11.2\%) mild stress, 146 (21\%) moderate stress and $251(36.1 \%)$ high stress.

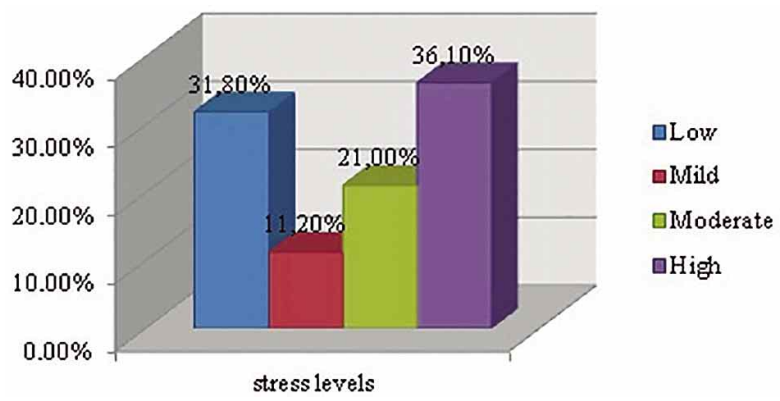

Fig. 2. Results of questionnaires about stress, the Social Readjustment Rating Scale (SRRS), applied to students of both sexes, of the University of Passo Fundo (UPF), in Passo Fundo, estate of RS, Brazil.

Table I. Distribution of the results about degree of TMD in the four studied areas of knowledge.

\begin{tabular}{|c|c|c|c|c|c|c|c|}
\hline \multirow[b]{2}{*}{ Area } & & \multicolumn{4}{|c|}{ TDM - Fonseca } & \multirow[b]{2}{*}{ Total } & \multirow[b]{2}{*}{$\mathbf{P}$} \\
\hline & & $\begin{array}{c}\text { No } \\
\text { TDM }\end{array}$ & $\begin{array}{l}\text { Mild } \\
\text { TDM }\end{array}$ & $\begin{array}{c}\text { Moderate } \\
\text { TDM }\end{array}$ & $\begin{array}{c}\text { Severe } \\
\text { TDM }\end{array}$ & & \\
\hline \multirow[t]{2}{*}{ Health } & $\mathrm{n}$ & 54 & 84 & 22 & 11 & 171 & \\
\hline & $\%$ & $26.1 \%$ & $27.2 \%$ & $15.7 \%$ & $27.5 \%$ & $24.6 \%$ & \\
\hline \multirow[t]{2}{*}{ Social } & $\mathrm{n}$ & 70 & 102 & 39 & 9 & 220 & \\
\hline & $\%$ & $33.8 \%$ & $33.0 \%$ & $27.9 \%$ & $22.5 \%$ & $31.6 \%$ & \\
\hline \multirow[t]{2}{*}{ Engineering } & $\mathrm{n}$ & 51 & 59 & 32 & 7 & 149 & 0.004 \\
\hline & $\%$ & $24.6 \%$ & $19.1 \%$ & $22.9 \%$ & $17.5 \%$ & $21.4 \%$ & \\
\hline \multirow[t]{2}{*}{ Linguistics. Letters and Arts } & $\mathrm{n}$ & 32 & 64 & 47 & 13 & 156 & \\
\hline & $\%$ & $15.5 \%$ & $20.7 \%$ & $33.6 \%$ & $32.5 \%$ & $22.4 \%$ & \\
\hline Total & $\mathrm{n}$ & 207 & 309 & 140 & 40 & 696 & \\
\hline
\end{tabular}

$5 \%$ of significance; $\mathrm{TMD}=$ Temporomandibular disorders.

Table II. Distribution of the results about stress levels in the four areas of knowledge studied.

\begin{tabular}{|c|c|c|c|c|c|c|c|}
\hline \multirow{2}{*}{ Area } & & \multicolumn{4}{|c|}{ Stress - SRRS } & \multirow{2}{*}{ Total } & \multirow{2}{*}{$\mathbf{P}$} \\
\hline & & Low & Mild & Moderate & High & & \\
\hline \multirow[t]{2}{*}{ Health } & $\mathrm{n}$ & 59 & 24 & 41 & 47 & 171 & \\
\hline & $\%$ & $26.7 \%$ & $30.8 \%$ & $28.1 \%$ & $18.7 \%$ & $24.6 \%$ & \\
\hline \multirow[t]{2}{*}{ Social } & $\mathrm{n}$ & 78 & 13 & 38 & 91 & 220 & \\
\hline & $\%$ & $35.3 \%$ & $16.7 \%$ & $26.0 \%$ & $36.3 \%$ & $31.6 \%$ & \\
\hline \multirow[t]{2}{*}{ Engineering } & $\mathrm{n}$ & 44 & 21 & 37 & 47 & 149 & 0.007 \\
\hline & $\%$ & $19.9 \%$ & $26.9 \%$ & $25.3 \%$ & $18.7 \%$ & $21.4 \%$ & \\
\hline \multirow[t]{2}{*}{ Linguistics. Letters and Arts } & $\mathrm{n}$ & 40 & 20 & 30 & 66 & 156 & \\
\hline & $\%$ & $18.1 \%$ & $25.6 \%$ & $20.5 \%$ & $26.3 \%$ & $22.4 \%$ & \\
\hline Total & $\mathrm{n}$ & 221 & 78 & 146 & 251 & 696 & \\
\hline
\end{tabular}

$5 \%$ of significance; SRRS= Social Readjustment Rating Scale. 
In dealing with areas of knowledge, it is described in Table I the distribution of the degree of TMD, according to data resulting from application of Fonseca's Questionnaire (TMD-F). It can be observed that in all areas the light TDM was the most prevalent, but no statistical difference was perceived between them $(p=0.004)$, according to the Chi-Square Test.

And the distribution of stress (SRRS) in these four studied areas is expressed in Table II. It can be observed that in the areas of the Applied Socials ( $n=$ 91), Engineering ( $n=47)$ and Literature, Language and Arts $(n=66)$, there was a larger number of interviewed with high level of stress, with statistical significance $(p=0.007)$, according the $X^{2}$ test, in all areas.
As for the correlation of the data TMD-F and stress (SRRS), it was weak ( $r=0.217)$, however, a significant difference is established by the $X^{2}$.

When the TMD-F and SRRS results were correlated, in the four knowledge areas researched, at the beginning of the semester (BS) and at the end of the semester (ES), in beginner students (BS) and senior students (SS) of the year 2012, the results were classified as weak positive and the results in the area of the Letters, Arts and Linguistics, at the beginning of the semester, had the correlation classified as insignificant negative ( $r=-0.028)$, as evidenced in the data of Table III.

Table III. Spearman correlation between TMD-F and SRRS, on the BS, ES, BS, SS in four major areas studied.

\begin{tabular}{|c|c|c|c|c|c|}
\hline \multirow{2}{*}{ Area } & BS & ES & BS & SS & \multirow{2}{*}{$\begin{array}{c}\text { All } \\
\text { students }\end{array}$} \\
\hline & \multicolumn{4}{|c|}{$r(n)$} & \\
\hline $\begin{array}{l}\text { Health } \\
\text { (n) }\end{array}$ & $\begin{array}{c}0.250 \\
(88)\end{array}$ & $\begin{array}{l}0.188 \\
(89)\end{array}$ & $\begin{array}{c}0.302 \\
(89)\end{array}$ & $\begin{array}{c}0.131 \\
(82)\end{array}$ & $\begin{array}{l}0.222 \\
(171)\end{array}$ \\
\hline $\begin{array}{l}\text { Social } \\
\text { (n) }\end{array}$ & $\begin{array}{c}0.168 \\
(98)\end{array}$ & $\begin{array}{l}0.258 \\
(122)\end{array}$ & $\begin{array}{l}0.215 \\
(120)\end{array}$ & $\begin{array}{l}0.244 \\
(100)\end{array}$ & $\begin{array}{l}0.236 \\
(220)\end{array}$ \\
\hline $\begin{array}{l}\text { Engineering } \\
\text { (n) }\end{array}$ & 0.287 & 0.282 & 0.267 & $\begin{array}{c}0.309 \\
(79)\end{array}$ & $\begin{array}{l}0.293 \\
(149)\end{array}$ \\
\hline $\begin{array}{l}\text { Linguistics. Letters and Arts } \\
\text { (n) }\end{array}$ & $\begin{array}{l}-0.028 \\
(77)\end{array}$ & $\begin{array}{c}0.161 \\
(79)\end{array}$ & $\begin{array}{c}0.055 \\
(81)\end{array}$ & $\begin{array}{l}0.068 \\
(75)\end{array}$ & $\begin{array}{l}0.075 \\
(156)\end{array}$ \\
\hline All students & $\begin{array}{l}0.182 \\
(350)\end{array}$ & $\begin{array}{l}0.236 \\
(346)\end{array}$ & $\begin{array}{l}0.242 \\
(360)\end{array}$ & $\begin{array}{l}0.187 \\
(336)\end{array}$ & $\begin{array}{l}0.217 \\
(696)\end{array}$ \\
\hline
\end{tabular}

$\mathrm{BS}=$ Beginning of the year; ES= Endo of semester; BS= Beginner students; $S \mathrm{~S}=$ Senior students.

\section{DISCUSSION}

Of the 696 participants, 257 (36.9\%) were male and $439(63.1 \%)$ female, indicating a higher percentage of women than men in the sample. This confirms the studies of Lipp \& Malagris (2004), Servilha (2005), Malagris \& Fiorito (2006) and Rossetti et al. (2008), indicating that there are changes in recent decades regarding the role of women in society, concerning various demands to which they are subjected, due to the fact that these woman accumulate several functions, work double shifts (housework and paid work), an accumulation that generates stress and fatigue.

The age of participants varied from 17 to 54 years, being the average age $21.7 \pm 4.57$ years and the median 21 years. As $57.1 \%$ of respondents showed higher levels of SRRS (21\% moderate and $36.1 \%$ high), the results are in accordance to the results found by Rossetti et al., who compared the frequency of stress among age groups and showed that the group aged between twenty and thirty years was the one that showed a higher index of stress $(49.0 \%)$ and in which the stress symptoms decrease with the advancement of age, since the older people enlarge their repertoire about confrontation of difficulties and increase the sense of self-efficacy.

The Fonseca's Questionnaire allows the collection of a large amount of information in a relatively short period of time and at low cost. It's easy to be understood and has practically no influence of the examiner, as showed by Fonseca et al., BevilaquaGrossi et al. (2006), Martins et al. (2007, 2010) and Nomura et al. Using a simplified questionnaire, these authors were able to recognize the symptoms that can lead to an increased wear out of TMJ and/or the stomatognathic system as a whole. 
Currently it can be said that there is a low percentage of individuals who are completely free of TMD (Okeson; Nekora-Azak et al.; Martins et al., 2007, 2010; Nomura et al., 2007), which was also observed in the present study, in which $70.2 \%$ of respondents had some degree of TMD-F. Only $29.74 \%$ were classified, according TMD-F and "with no TMD." On the other hand, in both studies of Martins et al. (2007, 2010), we found that $50.8 \%$ had some degree of TMD and $49.2 \%$ were considered with no TMD, according TMD-F. The large area of the Applied Social was where there was a higher prevalence $(48.54 \%)$ some degree of TMD, and, in this group, light TMD was the most frequent $(33 \%)$.

On TMD distribution and sex variant was possible to observe a prevalence of $70.76 \%$ in women with statistical difference $(p=0.001)$. Light TMD was most frequent in both, men and women. Bagis et al. (2012) found that women presented more frequently $(p=0.006)$ the signs and symptoms of TMD, as well as the use of antidepressants. Gomes et al. (2012) investigated the effect of electrical stimulation with cathodic high voltage on pain only in women with TMD, since there are studies (Gonçalves et al., 2010) that refer that these were most affected by this pathology. da Cunha et al. (2007) found no statistical difference in this variant (sex).

Regarding the degrees of TMD, light TMD was the most frequent, appearing in $44.4 \%$ (309 students interviewed) for the whole sample, as well as in the study of Martins et al., in which, although the percentage was lower ( $33 \%$ of the sample), light TMD was also the most frequent.

When dealing about SRRS, there was a variation in the four studied areas, with statistical significance $(p=$ $0.007)$. The high SRRS was more prevalent $(13.07 \%)$ in the area of the Applied Social and moderate SRRS in area of Health (5.9\%). Cerchiari (2004) observed, in a study with 558 university students from different areas, that psychosomatic disturbances (tension, psychological stress and poor performance) were prevalent among students of the nursing course. An index of $57.1 \%$ of respondents showed higher levels of SRRS $(21 \%$ moderate and $36.1 \%$ high), similar to the levels found by Martins et al. (59.5\%) in 2010, and slightly lower than the ones reported by Martins et al. in 2007, with $48.6 \%$ of interviewed with higher levels of stress (SRRS).

The higher frequency of indications of stress in women $(63.07 \%)$ is similar to those found by Lipp \&
Malagris, Servilha, Malagris \& Fiorito and Rossetti et al., indicating the relevance of future studies with this population. These studies should take into consideration the changes of the last decades in relation to the role of women in society, concerning the various demands to which they are subjected, due to the fact that these women work double shifts (housework and paid work), accumulation that generates stress and fatigue. However, neither Malagris \& Fiorito, nor Benavente \& Costa (2011) found significant differences between stressed men and women, as well as our findings, which, although evident, had no significance $(p=0.116)$.

There was no direct association of TMD-F with stress SRRS, as well as showed by a study of Venancio \& Camparis (2002), who concluded that professionals who treat patients with TMD should be aware of behavioral or psychological involvement in treatment response.

Pizolato et al. (2007) also concluded that stress does not influence the TMD and the bruxism. However, Martins et al. (2007, 2010) observed a statistically significant association between TMD and stress $(p<0.01)$, having the same questionnaires being used in this paper, TMD-F and SRRS, respectively. Fernandes et al. (2012), on the other hand, concluded that patients with moderate and severe TMD have an increased risk of having levels of depression and nonspecific physical symptoms, which occur with even greater significance in patients with nocturnal bruxism. Also in this line of statements, Fillingim et al. (2011) concluded that the probability of TMD were associated to higher levels of psychosocial symptoms and emotional problems.

Early identification of TDMs and stress on the academic universe can contribute to a diagnosis and to a more conservative treatment for university students with such alterations, contributing to an improvement in the quality of their lives.

RIFFEL, C. D. T.; FLORES, M. E.; SCORSATTO, J. T.; CECCON, L. V.; DE CONTO, F. \& ROVANI, G. Asociación de disfunción temporomandibular y estrés en estudiantes universitarios. Int. J. Odontostomat., 9(2):191-197, 2014.

RESUMEN: El objetivo de este estudio fue evaluar la influencia de los factores emocionales en los trastornos temporomandibulares (TTM) en estudiantes universitarios. Fueron estudiados 696 estudiantes de ambos sexos, de la Universidad de Passo Fundo (UPF) - RS, que recibieron el 
Cuestionario de Fonseca, con el fin de verificar el nivel de TTM y la Escala de Reajuste Social (ERS), para evaluar el grado de nivel de estrés, en dos momentos distintos, al principio y al final del semestre, tanto en estudiantes que ingresaron a la Universidad como en estudiantes que se gradúan. Los datos fueron tabulados y analizados estadísticamente mediante la prueba de chi-cuadrado, con un nivel de significación del 5\%. Del total, 489 (70,25\%) sujetos tenían algún grado de TTM, siendo el tipo leve de TTM el más frecuente (309) en todas las áreas del conocimiento, sin diferencia estadística entre las áreas estudiadas $(p=0,004)$. No hubo correlación entre los TTM y el estrés-ERS $(r=0,217)$. Existe un bajo porcentaje de las personas que están libres de TTM. La correlación entre los TTM y el estrés era débil en todos los grupos estudiados, independientemente del área de conocimiento, periodo académico y grado escolar.

PALABRAS CLAVE: articulación temporomandibular, dolor facial, estrés psicológico, síndrome de disfunción de la articulación temporomandibular.

\section{REFERENCES}

Bagis, B.; Ayaz, E. A.; Turgut, S.; Durkan, R. \& Özcan, M. Gender difference in prevalence of signs and symptoms of temporomandibular joint disorders: a retrospective study on 243 consecutive patients. Int. J. Med. Sci., 9(7):539-44, 2012.

Benavente, S. B. T. \& Costa, A. L. S. Respostas fisiológicas e emocionais ao estresse em estudantes de enfermagem: revisão integrativa da literatura científica. Acta Paul. Enferm., 24(4):571-6, 2011.

Bevilaqua-Grossi, D.; Chaves, T. C.; de Oliveira, A. S. \& Monteiro-Pedro, V. Anamnestic Index Severity and Signs and Symptoms of TMD. Cranio, 24(2):112-8, 2006.

Carlsson, G. E.; Magnusson, T. \& Guimarães, A. S. Tratamento das Disfunções Temporomandibulares na Clínica Odontológica. São Paulo, Quintessence, 2006.

Cerchiari, E. A. N. Saúde mental e qualidade de vida em estudantes universitários. Tese de Doutorado. Campinas, Faculdade de Ciências Médicas da Universidade Estadual de Campinas, 2004.

da Cunha, S. C.; Nogueira, R. V. B.; Duarte, A. P.; Vasconcelos, B. C. E. \& Almeida, R. A. C. Análise dos índices de Helkimo e craniomandibular para diagnóstico de desordens temporomandibulares em pacientes com artrite reumatóide. Rev. Bras. Otorrinolaringol., 73(1):1926, 2007.

Dworkin, S. F.; Huggins, K. H.; LeResche, L.; Von Korff, M.;
Howard, J.; Truelove, E. \& Sommers, E. Epidemiology of signs and symptoms in temporomandibular disorders: clinical signs in cases and controls. J. Am. Dent. Assoc., 120(3):273-81, 1990.

Fernandes, G.; Franco, A. L.; Siqueira, J. T.; Gonçalves, D. A. \& Camparis, C. M. Sleep bruxism increases the risk for painful temporomandibular disorder, depression and non-specific physical symptoms. J. Oral Rehabil., 39(7):538-44, 2012.

Ferreira, K. D. M.; Guimarães, J. P.; Batista, C. H. T.; Ferraz Júnior, A. M. L. \& Ferreira, L. A. Fatores psicológicos relacionados à sintomatologia crônica das desordens temporomandibulares - revisão de literatura. R. F. O. (Porto Alegre), 14(3):262-7, 2009.

Fillingim, R. B.; Ohrbach, R.; Greenspan, J. D.; Knott, C.; Dubner, R.; Bair, E.; Baraian, C.; Slade, G. D. \& Maixner, W. Potential psychosocial risk factors for chronic TMD: descriptive data and empirically identified domains from the OPPERA case-control study. J. Pain, 12(11 Suppl.):T46-60, 2011.

Fonseca, D. M.; Bonfante, G.; Valle, A. L. D. \& Freitas, S. F. T. Diagnóstico pela Anamnese da Disfunção Craniomandibular. R. F. O. (Porto Alegre), 42(1):23-4, 278, 1994.

Gomes, N. C. M. C.; Berni-Schwarzenbeck, K. C. S.; Packer, A. C. \& Rodrigues-Bigaton, D. Efeito da estimulação elétrica de alta voltagem catódica sobre a dor em mulheres com DTM. Rev. Bras. Fisioter., 16(1):10-5, 2012.

Gonçalves, D. A.; Dal Fabbro, A. L.; Campos, J. A.; Bigal, M. E. \& Speciali, J. G. Symptoms of temporomandibular disorders in the population: an epidemiological study. J. Orofac. Pain, 24(3):270-8, 2010.

Holmes, T. H. \& Rahe, R. H. The Social Readjustment Rating Scale. J. Psychosom. Res., 11(2):213-8, 1967.

Lipp, M. E. N. \& Malagris, L. E. N. O stress no Brasil de hoje. In: Lipp, M. N. (Ed.). Stress no Brasil: Pesquisas Avançadas. Campinas, Papirus, 2004. pp.215-22.

Malagris, L. E. N. \& Fiorito, A. C. C. Avaliação do nível de stress de técnicos da área de saúde. Estud. Psicol. (Campinas), 23(4):391-8, 2006.

Martins, R. J.; Garcia, A. R.; Garbin, C. A. S. \& Sundefeld, M. L. M. M. Association between economic class and stress in temporomandibular joint dysfunction. Rev. Bras. Epidemiol., 10(2):215-22, 2007.

Martins, R. J.; Garbin, C. A. S.; Garcia, A. R.; Garbin, A. J. I.; Miguel, N. Stress levels and quality of sleep in subjects with temporomandibular joint dysfunction. Rev. Odonto. Ciênc., 25(1):32-6, 2010. 
RIFFEL, C. D. T.; FLORES, M. E.; SCORSATTO, J. T.; CECCON, L. V.; DE CONTO, F. \& ROVANI, G. Association of temporomandibular dysfunction and stress in university students. Int. J. Odontostomat., 9(2):191-197, 2015.

Nekora-Azak, A.; Evlioglu, G.; Ordulu, M. \& Is, sever, H. Prevalence of symptoms associated with temporomandibular disorders in a Turkish population. J. Oral Rehabil., 33(2):81-4, 2006.

Nóbrega, J. C.; Siqueira, S. R.; Siquiera, J. T. \& Teixeira, M. J. Diferential diagnosis in atypical facial pain: a clinical study. Arq. Neuropsiquiatr., 65(2A):256-61, 2007.

Nomura, K.; Vitti, M.; Oliveira, A. S.; Chaves, T. C.; Semprini, M.; Siéssere, S.; Hallak, J. E. \& Regalo, S. C. Use of the Fonseca's questionnaire to assess the prevalence and severity of temporomandibular disorders in Brazilian dental undergraduates. Braz. Dent. J., 18(2):163-7, 2007.

Okeson, J. P. Etiologia e identificação dos distúrbios funcionais do sistema mastigatório. In: Okeson, J. P. Tratamento das desordens temporo-mandibulares e oclusão. 4a ed. São Paulo, Artes Médicas, 2000. pp.117272.

Pizolato, R. A.; Gavião, M. B. D.; Berretin-Felix, G.; Sampaio, A. C. M. \& Trindade Junior, A. S. Maximal bite force in young adults with temporomandibular disorders and bruxism. Braz. Oral Res., 21(3):278-83, 2007.

Rosseti, M. O.; Ehlers, D. M.; Guntert, I. B.; Sá Leme, I. F. A; Rabelo, I. S. A.; Tosi, S. M. V. D.; Pacanaro, S. V. \& Barrionuevo, V. L. O inventário de sintomas de stress para adultos de lipp (ISSL) em servidores da polícia ederal de São Paulo. Rev. Bras. Ter. Cogn., 4(2):108-20, 2008.

Servilha, E. A. M. Estresse em professores universitários na área de fonoaudiologia. Rev. Ciênc. Méd. (Campinas), 14(1):43-52, 2005.

Sessle, B. J. Acute and chronic craniofacial pain: Brainstem mechanisms of nociceptive transmission and neuroplasticity, and their clinical correlates. Crit. Rev. Med. Oral Biol., 11(1):57-91, 2000.

Thailander, B.; Rubio, G.; Pena, L. \& de Mayorga, C. Prevalence of temporomandibular dysfunction and its association with malocclusion in children and adolescents: an epidemiologic study related to specified stages of dental development. Angle Orthod., 72(2):146-54, 2002.

Venancio, R. A. \& Camparis, C. M. Estudo da relaçäo entre fatores psicossociais e desordens têmporo-mandibulares. Rev. Bras. Odontol., 59(3):152-4, 2002.

\author{
Correspondencet to: \\ Caroline Dias Tams Riffel \\ Rua General Neto, 1769 \\ Fatima neighborhood \\ Passo Fundo- RS \\ CEP-99020-050 \\ BRAZIL
}

Email: cdtriffel@gmail.com

Received: 03-12-2014

Accepted: 23-04-2015 